no.

GL-92-16

c. 2

P-UG-92/04
1992
MP GL-92-16
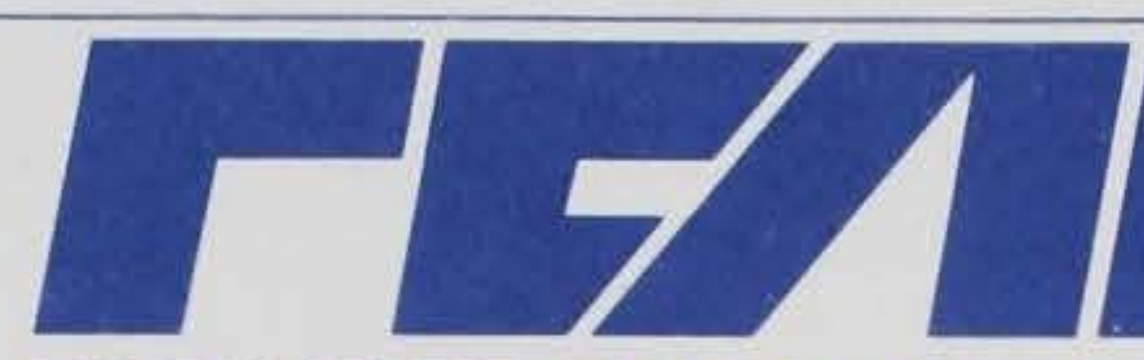

FACILITIES ENGINEERING

USER'S GUIDE

MP GL-92-16

\title{
APPLICATIONS PROGRAM
}

\section{USER'S GUIDE: GEOTEXTILES AS SEPARATION LAYERS IN PAVEMENT STRUCTURES}

\author{
US-CE-C PROPERTY OF THE \\ UNITED STATES GOVERNMENT
}

by

James E. Shoenberger

US Army Engineer Waterways Experiment Station

Vicksburg, MS 39180-6199

RESEARCH LIBRARY

US ARMY ENGINEER WATERWAYS

EXPERIMENT STATION

VICKSBURG, MISSISSIPPI

Approved For Public Release; Distribution Is Unlimited

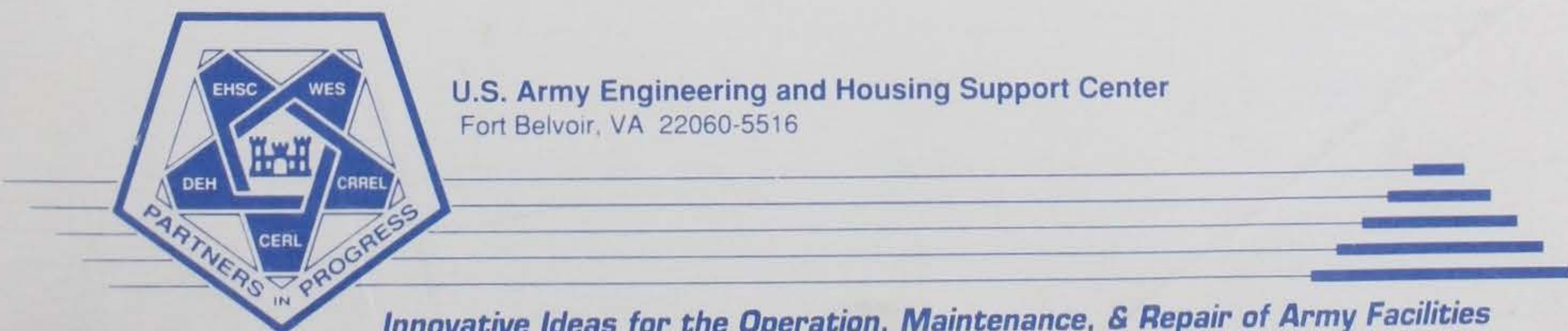

Innovative Ideas for the Operation, Maintenance, \& Repair of Army Facilities 
Public reporting burden for this collection of information is estimated to average 1 hour per response, including ine time for reviewing instructions, searching existing data sources. gathering and maintaining the data needed. and completing and reviewing the collection of information. Send comments regarding this burden estimate or any other aspect of this Davis Highway. Suite 1204. Arlington, VA 22202-4302, and to the Otfice of Management and Budget, Paperwork Reduction Project (0704-0188), Washington. DC 20503.

\begin{tabular}{|l|c|c|}
\hline 1. AGENCY USE ONLY (Leave blank) & $\begin{array}{c}\text { 2. REPORT DATE } \\
\text { June } 1992\end{array}$ & $\begin{array}{c}\text { 3. REPORT TYPE AND DATES COVERED } \\
\text { Final report }\end{array}$ \\
\hline
\end{tabular}

4. TITLE AND SUBTITLE

User's Guide: Geotextiles as Separation Layers

in Pavement Structures

5. FUNDING NUMBERS

\section{AUTHOR(S)}

James E. Shoenberger

7. PERFORMING ORGANIZATION NAME(S) AND ADDRESS(ES)

USAE Waterways Experiment Station

Geotechnical Laboratory

3909 Halls Ferry Road

Vicksburg, MS 39180-6199
8. PERFORMING ORGANIZATION REPORT NUMBER

Miscellaneous Paper GL- $92-16$

10. SPONSORING /MONITORING AGENCY REPORT NUMBER

FEAP-UG - $92 / 04$

US Army Corps of Engineers

Engineering and Housing Support Center

Bldg. 2593

Fort Belvoir, VA 22060-5516

11. SUPPLEMENTARY NOTES

Approved for public release; distribution is unlimited.

\section{ABSTRACT (Maximum 200 words)}

The user's guide provides the technical information required to implement application of geotextiles as separation layers in pavement structures. Included are details on areas of application, benefits/advantages, limitations/ disadvantages, and costs associated with this technology. Information on two demonstration sites at Fort Carson, CO, and Fort Knox, KY, is provided. Also provided is information concerning funding, procurement, maintenance, and performance monitoring. A summary of the demonstrations and references are provided in the appendices.

\begin{tabular}{|c|c|c|c|}
\hline \multirow{2}{*}{\multicolumn{3}{|c|}{$\begin{array}{l}\text { 14. SUBJECT TERMS } \\
\text { Aggregate surfaced roads Separation } \\
\text { Fabric } \\
\text { Geotextile }\end{array}$}} & \multirow{2}{*}{$\begin{array}{l}\text { 15. NUMBER OF PAGES } \\
23 \\
\text { 16. PRICE CODE }\end{array}$} \\
\hline & & & \\
\hline $\begin{array}{l}\text { 17. SECURITY CLASSIFICATION } \\
\text { OF REPORT } \\
\text { Unclassified }\end{array}$ & $\begin{array}{l}\text { 18. SECURITY CLASSIFICATION } \\
\text { OF THIS PAGE } \\
\text { Unclassified }\end{array}$ & $\begin{array}{l}\text { 19. SECURITY CLASSIFICATION } \\
\text { OF ABSTRACT } \\
\text { Unclassified }\end{array}$ & 20. LIMITATION OF ABSTRACT \\
\hline
\end{tabular}


CONTENTS

$\underline{\text { Page }}$

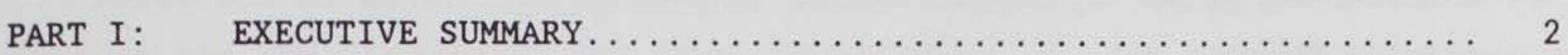

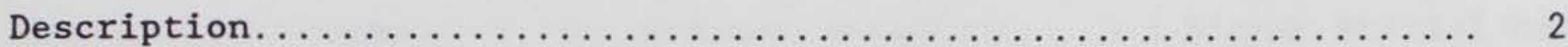

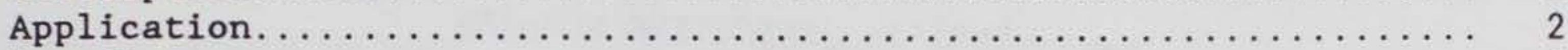

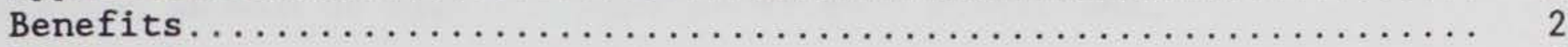

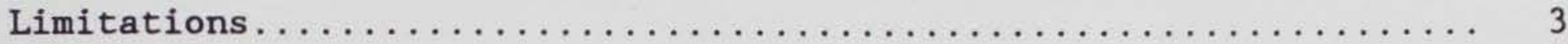

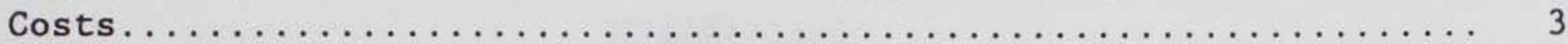

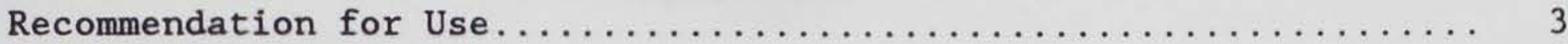

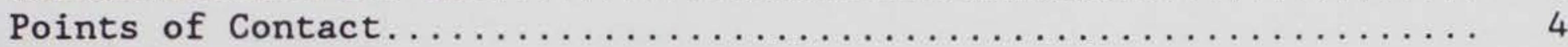

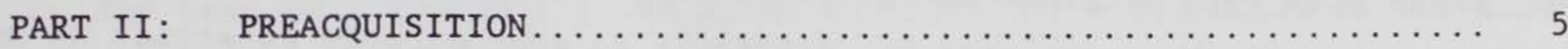

Description of Geotextiles as Separation Layers............. 5

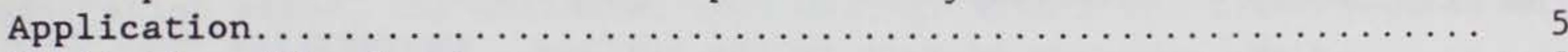

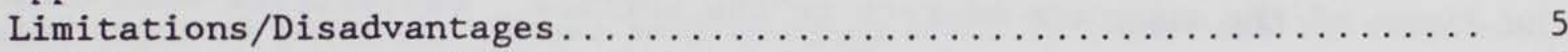

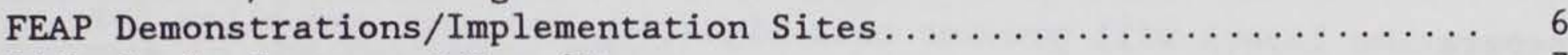

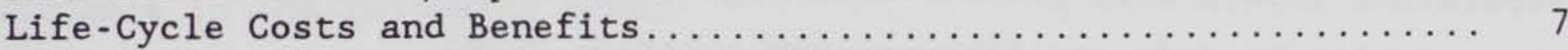

PART III: ACQUISITION/PROCUREMENT $\ldots \ldots \ldots \ldots \ldots \ldots \ldots \ldots \ldots \ldots \ldots \ldots \ldots \ldots \ldots \ldots$

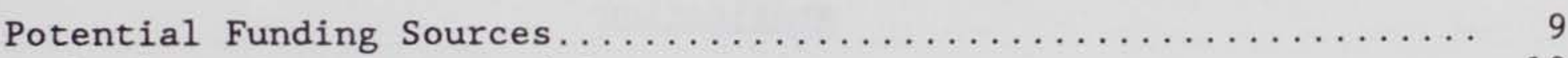

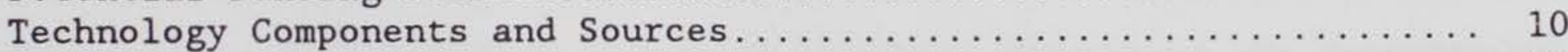

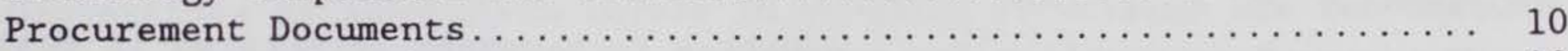

Procurement Scheduling........................... 10

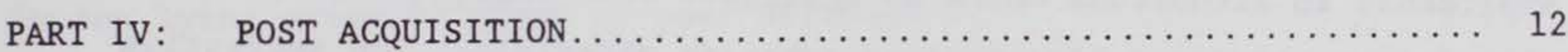

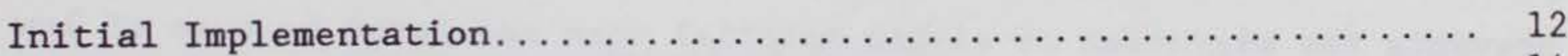

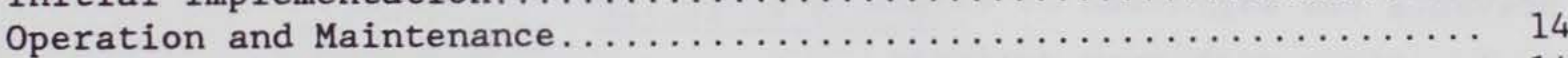

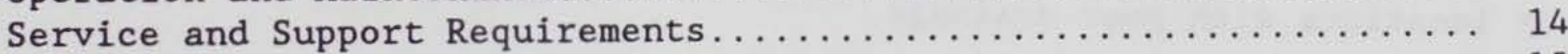

Performance Monitoring. ........................... 15

TABLES $1-3$

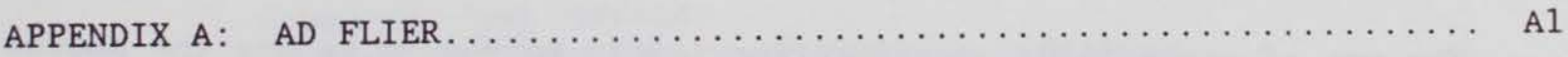




\section{USER'S GUIDE: GEOTEXTILES AS SEPARATION LAYERS IN PAVEMENT STRUCTURES}

\section{PART I : EXECUTIVE SUMMARY}

\section{Description}

Areas with soft subgrade materials or with fine-grained materials which will become soft when saturated are difficult to economically construct on as the base course or cover material will tend to migrate into the subgrade while the fines of the subgrade migrate to the surface. Geotextiles when used as separation layers will prevent this migrating movement and allow for construction in soft and fine-grained subgrade areas.

\section{Application}

The use of geotextiles for separation in pavement structures is most applicable in situations where an aggregate base course or cover material is placed over saturated fine-grained subgrade materials. The geotextile prevents the migration of either material when saturated because of low areas or locations with poor drainage.

\section{Benefits}

The use of geotextiles as separation layers serves to reduce the amount of cover material required and to reduce long term maintenance requirements. The geotextiles will prevent vertical migration of the materials to reduce the amount of cover material required and to increase the bearing strength of the pavement structure and reduce rutting when the subgrade is saturated. The amount of maintenance required is reduced by preventing fines from migrating to the surface, requiring the addition of more cover material. 


\section{Limitations}

There are no major limitations or disadvantages to using geotextiles as long as the additional initial cost can be offset by the reduced maintenance and improved performance of the pavement structure. This higher initial cost limitation should be easily offset under most conditions.

\section{Costs}

The cost of a geotextile can often be offset by a reduction in the amount of cover material required during the initial construction. At the demonstration sites, the estimated cost savings within the first year were greater than 20 percent. These cost savings will increase due to reduced maintenance in the following years.

\section{Recommendation for Use}

Geotextiles as separation layers in pavement structures are recommended for use in areas of construction over soft or fine-grained soils, especially in low lying areas or areas of poor drainage.

\section{Points of Contact}

Points of contact regarding this technology are:

Technical:

Commander and Director

US Army Engineer Waterways Experiment Station

ATTN: CEWES-GP-Q (Mr. James E. Shoenberger)

3909 Halls Ferry Road

Vicksburg, MS 39180-6199

Telephone: (601) 634-3553

Facsimile: (601) 634-3139 
US Army Engineering and Housing Support Center:

Commander

US Army Engineering and Housing Support Center

ATTN: CEHSC-FB-P (Mr. Stan Nicke11)

Fort Belvoir, VA 22060-5516

Telephone: (703) 355-0040

Facsimile: (703) 780-5935

Points of contact at demonstration sites:

Fort Carson:

Directorate of Engineering and Housing

ATTN: AFZC-FE-MP (Mr. Rick Rhodus)/FE-MB (Ms. Laura Levi)

Building 304

Fort Carson, CO 80913-5023

Telephone: (719) 579-3038

Fort Knox:

Director of Engineering Plans and Services

ATTN: USAAR MC (Mr. Warren Clifford)

Fort Knox, KY 40121-5000

Telephone: (502) 624-7648 


\section{Description of Geotextiles as Separation Layers}

Geotextiles are used as separation layers to prevent the intrusion of the existing soil or subgrade into the cover material and prevent the cover material from migrating into the subgrade. Geotextiles can be used as long term solutions to soft subgrade problems, and they can also be used in expedient applications. Most geotextiles, when not exposed to direct sunlight or traffic wear, will last almost indefinitely. Expedient uses could include construction haul roads and temporary parking areas for vehicles.

\section{Application}

The use of a geotextile as a separation layer is advantageous under several conditions. One situation is when the underlying material is very soft (often due to a high moisture content) and placement of the geotextile prevents intrusion of this material into the gravel or aggregate overlay. The geotextile may be used in low areas or areas of poor drainage which tend to become saturated and lose strength. The geotextile will also increase the bearing structure of the soil system by elongating the geotextile and rutting in the wheel paths on the surface.

\section{Limitations/Disadvantages}

One disadvantage of using geotextiles is the increased labor cost involved in handling and placing the materials. When utilizing large amounts of geotextiles, special equipment can be purchased or made to facilitate the handling and placement process and reduce the labor involved. In most instances the amount of base or cover material saved will more than outweigh the cost of the extra labor and the geotextile. 


\section{FEAP Demonstrations/Implementation Sites}

Demonstration projects were conducted at Fort Carson, CO, and at Fort Knox, KY, using geotextiles as separation layers.

The demonstration project at Fort Carson involved rehabilitating 5,000ft-long by 60 -ft-wide unpaved Red Devil airfield. The existing airstrip had required frequent maintenance due to the existing clay subgrade which softened when saturated causing rutting and a reduction in use. During extremely wet periods, the runway could not be used at all. The factors used for the airfield design included a subgrade CBR of $5.9,5,000$ passes of the $C-130$ aircraft, a 30-kip axle load, 100-psi tire pressure, and an acceptable rut depth of 2 in. The demonstration project included grading and compacting of the existing subgrade, placing the geotextile over the existing subgrade, and then placing and compacting a crushed base course surfacing material. The subgrade and the crushed surface aggregate were compacted to 95 and 100 percent, respectively, of CE 55 maximum density. The geotextile used was a woven slit film geotextile. It was designed for very high survivability as required in TM 5-818-8, with a minimum grab strength of $270 \mathrm{lb} / \mathrm{in}$. At the time of construction, the subgrade was dry and construction traffic was allowed on the geotextile. During the construction, a section of the geotextile was torn; a section of geotextile was laid over the tear extending several feet on all sides and overlaid with compacted base aggregate. This repaired section has performed as well as the surrounding areas. This runway is now usable under most wet weather conditions.

The demonstration project at Fort Knox involved upgrading an existing unpaved road named South Boundary Cut-off Road. The road was being upgraded to carry an increased amount of traffic and to make the road usable during periods of wet weather. The approximately 2 -mile-long roadway was being widened to a minimum usable width of $28 \mathrm{ft}$. The roadway was graded, drainage ditches were constructed as required along the road, and pipes were placed where cross drainage was required. The demonstration site was approximately 1,200 ft long and the full width of the road. The geotextile was unrolled on the graded roadway, and 6 in. of well-graded crushed stone was placed on top. The geotextile used was a Burke-Tex ST 60 manufactured by Bradley Materials. This nonwoven geotextile was designed for moderate survivability, with a 
minimum grab strength of $130 \mathrm{lb} / \mathrm{in}$. The $300 \mathrm{ft}$ by $15.5 \mathrm{ft}$ rolls were placed by hand. Varying wind conditions required occasionally weighing down the geotextile's edges to prevent movement. Trucks end-dumped onto the geotextile, and the aggregate was spread by a loader and a grader without trafficking directly on the geotextile. The remainder of the roadway that did not receive the geotextile required a more coarse stone layer prior to the graded aggregate. Contact with DEH personnel after one winter's use indicated that the geotextile section was performing better than the remainder of the road. The section with the geotextile required less frequent reshaping and grading. The remainder of the roadway will apparently require additional aggregate to correct some soft areas.

\section{Life-Cycle Costs and Benefits}

\section{Costs}

The cost of using a geotextile, as with most construction materials, is lowered as the amount of material required increases. Approximately 39,000 and 4,200 sq yd of geotextile were used at Fort Carson and Fort Knox, respectively. The geotextile costs at Fort Carson and Fort Knox were \$0.64 and $\$ 0.59 / \mathrm{sq} y d$, respectively. The labor costs for placement are not usually that much except under extremely adverse weather conditions. At Fort Carson where comparable sections without geotextile would have required an additional 3 in. of cover material, the initial savings at construction were approximately 10 percent. At Fort Knox where comparable sections without the geotextile required on average an additional 4 in. of cover aggregate, either during initial construction or within 1 year, the savings within this time frame would be greater than 20 percent. This percent savings would increase with time as the road sections without the geotextile require more maintenance and additional materials. 


\section{Advantages/Benefits}

A geotextile when used as a separation layer can reduce the need for large amounts of cover materials and maintenance costs. The specific advantages include:

a. Preventing of subgrade intrusion into the cover material and vice versa, resulting in a reduction of the amount of cover materials required.

b. Providing for economical construction over soft subgrades.

c. Lowering maintenance costs through less grading and adding of materials.

d. Improving long term performance and riding conditions. 


\section{PART III: ACQUISITION/PROCUREMENT}

\section{Potential Funding Sources}

Typically, installations fund the implementation of pavements and railroads technologies out of their annual budgets. However, the annual budget is always underfunded and normally the pavements and railroads projects just do not compete well with other high visibility/high interest type projects. As a result, it is in your best interest to seek all of the funds possible from other sources when the project merits the action. Listed below are some sources commonly pursued to fund projects.

a. Productivity program. See AR 5-4, Department of the Army Productivity Improvement Program for guidance to determine if the project qualifies for this type of funding.

b. Facilities Engineering Applications Program (FEAP). In the past, a number of pavement and railroad maintenance projects located at various installations were funded with FEAP demonstration funds. At that time, emphasis was placed on demonstrating new technologies to the Directorate of Engineering and Housing (DEH) community. Now that these technologies have been demonstrated, the installations will be responsible for funding their projects through other sources. However, emphasis concerning the direction of FEAP may change in the future; therefore, don't rule out FEAP as a source of funding.

c. Special programs. Examples of these are as follows:

(1) FORSCOM mobilization plan which may include rehabilitation or enlargement of parking areas and the reinforcement of bridges.

(2) Safety program which may include the repair of unsafe/ deteriorated railroads at crossings and in ammunition storage areas.

(3) Security upgrade which may include the repair or enlargement of fencing.

d. Reimbursable customer. Examples of this source are roads to special function areas such as family housing or schools and airfield pavements required to support logistical operations.

e. Special requests from MACOMS.

f. Year end funds. This type funding should be coordinated with the MACOMS to ensure that the funds will not be lost after a contract is advertised. 
g. Operations and Maintenance Army (OMA). These are the normal funds used for funding pavement and railroad projects.

\section{Technology Components and Sources}

Components of the technology which must be procured for the use of geotextiles as separation layers are section design (may be in-house or contracted out) and a contractor to place the geotextile and the cover aggregate. Geotextiles are widely used in the construction industry and most contractors will have had at least some experience in working with them. Geotextile manufacturers can provide support on products and usage. The Corps of Engineers has (at least in draft form) guide specifications and design and construction manuals covering the use of geotextiles.

\section{Procurement Documents}

A Corps of Engineers guide specification for geotextiles for separation of pavement layers has not been published. The demonstrations at each site used in-house personnel for construction and a formal specification was not developed at either site. A draft of a guide specification has been developed, partly from experience drawn from these demonstration projects. Technical Manual TM 5-822-3 "Design of Aggregate Surfaced Roads and Airfields" is available for the design of aggregate surfaced roads using geotextiles as separation layers.

\section{Procurement Scheduling}

No special procurement scheduling or planning is required to implement the use of a geotextile as a separation layer. All items to be procured are normally readily available and easily obtainable. The one exception could be a small order of a particular type of geotextile might not be readily available; however, substitution of a geotextile of higher quality could be a time effective solution under these circumstances. 


\section{PART IV: POST ACQUISITION}

\section{Initial Implementation}

\section{Equipment}

Geotextiles require no special equipment for construction, although specialized equipment is available and should be considered when large amounts of geotextiles are to be used. Conventional construction equipment and procedures are used preparing the subgrade and base course cover material. Material

The geotextile used for the separation layer is selected according to the condition of the subgrade, the amount of ground pressure exerted by the construction equipment, the type of cover material used, and the thickness of the initial lift. The condition of the subgrade is divided into three groups ranging from a relatively smooth surface to one which may contain stumps, holes, or large boulders. These conditions are used along with three divisions of low, medium, and high ground pressure to select a degree of fabric survivability as presented in Table 1 . The cover material is divided into three groups ranging from fine sand and gravel to large aggregate pieces (greater than one-half the lift thickness) with sharp edges and few fines. Table 2 presents the cover material groups versus the initial lift thickness in conjunction with the construction equipments ground pressure to select a degree of fabric survivability. The degrees of survivability range (Tables 1 and 2) are low, moderate, high, and very high, and geotextile is not recommended for high ground pressure equipment with minimal site preparation (Table 1). Table 3 presents various fabric material properties required for a degree of survivability.

The cover material used will often depend on locally available materials and the reason for the separation layer. The type and size of cover material selected has an effect on the type of geotextile selected (Table 2). When the cover aggregate is used as a base course for other pavement layers or as a surface course for an unpaved pavement, it should meet the requirements as provided in Table 1 of CEGS-02233 (Graded-Crushed-Aggregate Base Course). 


\section{Personne1}

Normal pavement construction personnel can be used in construction of geotextiles as separation layers. At the Fort Carson demonstration, the construction of the runway was accomplished by US Army troops of the 52nd Engineer Battalion. At the Fort Knox demonstration, the construction was accomplished by DEH personnel. Installation personnel at both locations provided contracting for the delivery of all materials with input for design and selection from WES. These types of projects could be contracted out for larger jobs or where in-house personnel are not available.

\section{Procedure}

Given the need for the addition of aggregate to a section of pavement, the procedure has three major steps: (1) establish the cost effectiveness of using a geotextile as a separation layer; (2) if cost effective, design and select the proper geotextile and the cover material; and (3) construct the pavement section using the geotextile and cover material.

The cost of the geotextile and its placement will be additional costs to the original construction. To establish the cost effectiveness of this process, the added cost of the geotextile must be compared to the increased cost of additional cover material and maintenance. Conditions such as type of traffic, type of loading, and weather (rainfall amounts) should be evaluated during a cost analysis.

If cost effective, the design of the pavement section is completed. Considering the factors addressed in Tables 1, 2, and 3 , the requirements for the geotextile can be developed. The cover material is also selected at this time, and the type selected will have an impact on the geotextile used. The geotextile can be specified according to the requirements listed in Table 3 . The cover material may be specified to utilize a specific local material or CEGS-02233 may be used. The design should also address drainage of surface water. The use of drainage ditches and culverts if required to control surface drainage will increase the life of the pavement structure and reduce maintenance costs.

Once the design and selection of materials are completed, the steps in the construction of the geotextile separation layer are:

a. Prepare the existing subgrade as accounted for in the design phase in selecting the type of geotextile to be used. This would include 
grading to the proper crown and preparing drainage structures as required. Depending on the site conditions and the design, compaction of the subgrade may or may not be required.

b. Place the geotextile on the existing subgrade allowing a suitable amount of overlap between separate pieces of the geotextile. The amount of overlay will need to increase as the softness of the subgrade increases. A minimum overlap should be $1 \mathrm{ft}$ longitudinally and $2 \mathrm{ft}$ in the transverse direction. The geotextile can be placed by hand or on larger jobs the contractor may have purchased or made by himself some equipment to facilitate the placement of the geotextile.

c. Place the cover material on the geotextile in such a manner as to avoid forming creases or tears. The bearing capacity of the subgrade at the time of construction will control whether construction equipment can traffic directly on the subgrade. When the subgrade will not support trafficking, the geotextile can be rolled out and the cover material can be end-dumped on or near the edge of the geotextile and worked outward. By keeping a minimum thickness (usually twice the maximum size aggregate), the material can be placed without tearing the geotextile or causing excess rutting in soft subgrades.

d. Depending on the pavement use and materials, the cover aggregate may require compaction. In most unpaved road applications where a well graded, crushed aggregate is used, the cover material will not require compaction.

\section{Operation and Maintenance}

The operation and maintenance procedures for cover aggregates over a geotextile are not different than that of normal unpaved pavements.

Experience has shown that with the geotextile separating the base course aggregate from the subgrade, the amount of cover material required can be initially and substantially reduced over the life of the pavement. The amount of maintenance (grading and/or adding additional aggregate) is reduced where a geotextile is utilized. Geotextiles have an indefinite life expectancy when buried under cover material.

\section{Service and Support Requirements}

No special services or support is required to implement or maintain this technology. 


\section{Performance Monitoring}

Installation personnel can monitor and measure the performance of the geotextile by keeping records of required maintenance of pavement sections with and without geotextiles. This monitoring should be based on sections with similar subgrade and should cover material, age, and trafficking conditions. Details required for in-depth cost analysis for judging future use should include date maintenance was performed, type of maintenance, and cost (time expended, materials and equipment required, and labor). 
Table 1. Required degree of faliric survivability (see Table 2) as a function of subgrade conilitions and construction equipment (FIIWA 1984)

\section{Subgrade Condtitions}

Subgrade has been cleared of all obstaclea except grass, weeds, leaves, and fine wood debris. Surface 18 smooth and level such that any shallow depressions and humps do not exceed 6 inches in depth and helght. Alterliatively, a smooth working table may be placed.

Subgrade has been cleared of obstacles larger than small- to moderate-sized tree limbs and rocks. Tree trunks and atumps should be removed or covered with a partial working cable. lepressions and humps should not exceed 18 inches In depth and helght. larger depressions should be till ed.

Mlinlmal site preparition ly required. Trees mily be felled, dellmbed, and left in place. Stumps should be cut to project not more than 6 inches above subgrade. Fabric may he draped directly over the tree trunks, stumps, large depressions and humps, holes, stream channels, and large boulders. Items should be removed only if placing the fabric and cover material over them will distort the fin-

Islied roud surface.

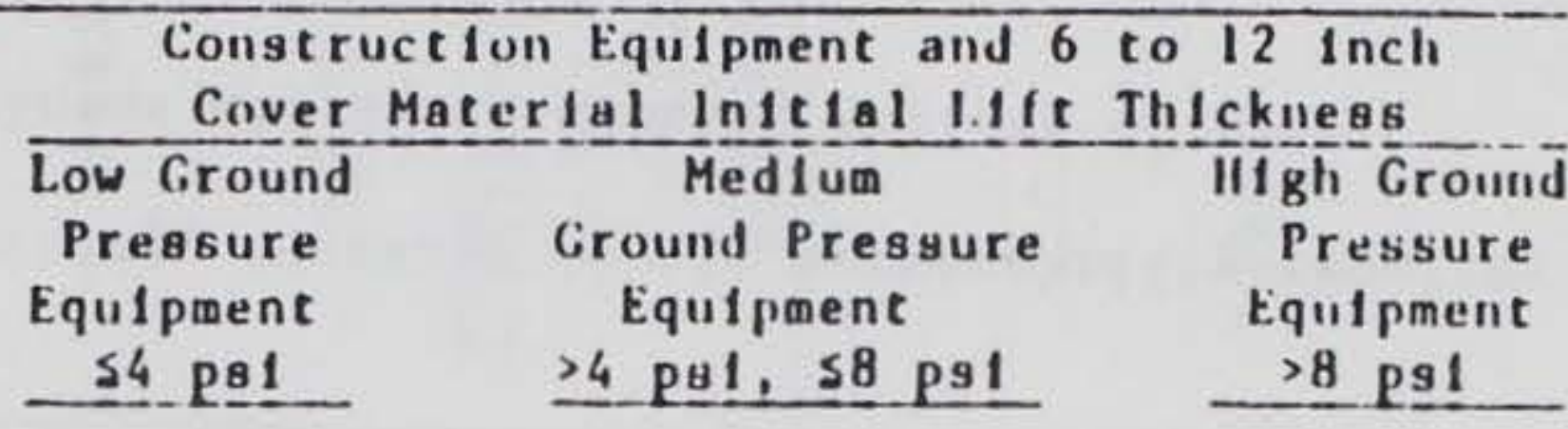

Low

Moderate

$111 \mathrm{gh}$
High

Very high
Not

'Notes:

1. Recunmendations are for 6 to 12 inch In1tial lift thicknesses. For other Inltial lift thlckness:

12 to 18 inch: Reduce survivabllity requirement 1 level

18 to 24 Inch: Reduce survivabllity requirement 2 levels $>24$ inch: Reduce survivabllity requlrement 3 levels

2. Survivability levels are, In increasing order: low, moderate, high, and very high. For special construction techniques such as pre-rutting. Increase fabric survivability requirement 1 level.

3. Placement of excessive inltial cover naterial thickness may cause bearing fallure of soft subgrades. 
Table 2 . Required degree of fabric survivability as a function of cover material and construction equipment (FHWA 1984)

\begin{tabular}{|c|c|c|c|c|c|c|}
\hline \multirow[b]{2}{*}{ Cover Mater1al } & \multicolumn{2}{|c|}{ 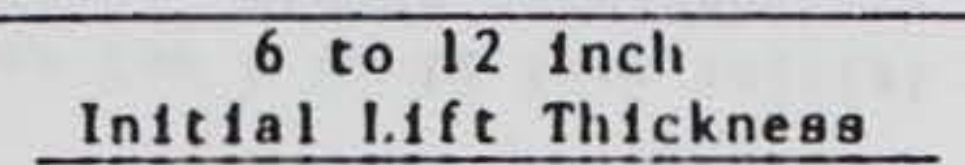 } & \multicolumn{2}{|c|}{ 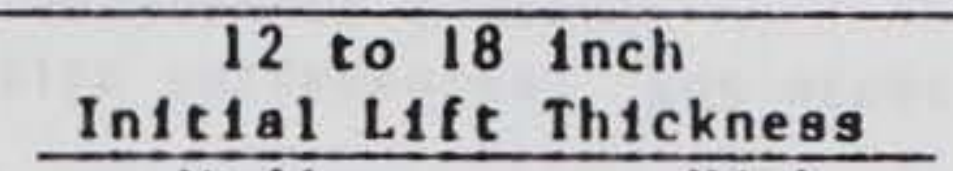 } & \multirow{2}{*}{$\begin{array}{l}18 \text { to } 24 \text { Inch } \\
\text { In1tial Lift } \\
\text { Th1ckness, } \\
\text { HIgh Ground } \\
\text { Pressure } \\
\text { Equ1pment } \\
>8 \text { p } 1 \\
\end{array}$} & \multirow{2}{*}{$\begin{array}{c}>24 \text { Inch } \\
\text { In1t 1:al l.1ft } \\
\text { Th1ckness, } \\
\text { H1gh liround } \\
\text { Pressure } \\
\text { Equipment } \\
>8 \text { ps }\end{array}$} \\
\hline & $\begin{array}{l}\text { Low } \\
\text { Ground } \\
\text { Pressure } \\
\text { Equ1pment } \\
\text { s4 ps1 } \\
\end{array}$ & $\begin{array}{c}\text { Medium } \\
\text { Ground } \\
\text { Pressure } \\
\text { Equ1pment } \\
>4 \text { P81, } \leq 8 \text { P81 }\end{array}$ & $\begin{array}{c}\text { Medium } \\
\text { Ground } \\
\text { Pressure } \\
\text { Equ1pment } \\
>4 \text { P 1, } \leq 8 \text { p81 } \\
\end{array}$ & 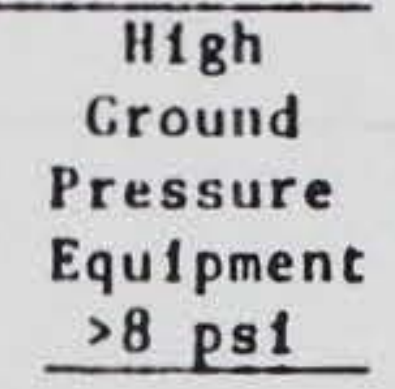 & & \\
\hline $\begin{array}{l}\text { Fine sand to } \pm 2-1 \mathrm{n},-\mathrm{d} 1 \text { am } \\
\text { gravel, rounded to } \\
\text { subangular }\end{array}$ & Low & Moderate & Low & Moderate & Low & low \\
\hline $\begin{array}{l}\text { Coarse aggregate with } \\
\text { dlameter up to one-half } \\
\text { proposed lift thick- } \\
\text { ness, may be angular }\end{array}$ & Moderate & $\mathrm{H} / \mathrm{gh}$ & Moderate & $111 \mathrm{gh}$ & Moderate & l.ow \\
\hline $\begin{array}{l}\text { Sume to most aggregate } \\
\text { with diameter greater } \\
\text { than one-half proposed } \\
\text { lift thickness, angular } \\
\text { and sharp-edge tew } \\
\text { fincs }\end{array}$ & $\mathrm{H}_{\mathrm{g}} \mathrm{gh}$ & Very $h 1_{g h}$ & $\mathrm{H} 1 \mathrm{gh}$ & Very $h l_{g} h$ & $111 \mathrm{gh}$ & Moderate \\
\hline
\end{tabular}

Notes:

1. For special construction techniques such as pre-rutting, increase fabric survivability requirement 1 level.

2. Placement of excessive initial cover material thickness may cause bearing fallure of solt subgrades. 
Table 3. AASHTO-AGC-ARTBA joint committee (interim specifications) minimum fabric properties required for fabric survivability

(FHWA 1984)

\begin{tabular}{|c|c|c|c|c|}
\hline $\begin{array}{c}\text { Required } \\
\text { Degree } \\
\text { of Fabric } \\
\text { Survivability } \\
\end{array}$ & $\begin{array}{l}\text { Grab Strength } \\
\text { (minimum values) } \\
1 \mathrm{~b} \\
\end{array}$ & $\begin{array}{l}\text { Puncture } \\
\text { Strength } \\
\text { lb } \\
\end{array}$ & $\begin{array}{l}\text { Burst } \\
\text { Strength } \\
\text { psi } \\
\end{array}$ & $\begin{array}{l}\text { Trap } \\
\text { Tear } \\
1 b \\
\end{array}$ \\
\hline Very high & 270 & 110 & 430 & 75 \\
\hline $\mathrm{H} 1 \mathrm{gh}$ & 180 & 75 & 290 & 50 \\
\hline Moderate & 130 & 40 & 210 & 40 \\
\hline Low & 90 & 30 & 145 & 30 \\
\hline
\end{tabular}

1. All values represent minfmum average roll values (1.e., any roll in a lot should meet or exceed the minimum values in this table). Note: These values are normally 20 percent lower than manufacturers reported typical values.

2. ASTM D 571-68, Tension Testing Machine with ring clamp, steel ball replaced with a 5/16-inch diameter solid steel cylinder with flat tip centered within the ring clamp.

3. ASTM D 751-68, D1aphragm Test Method.

4. ASTM D 1117, e1ther principal direction. 
APPENDIX A: AD FLIER 


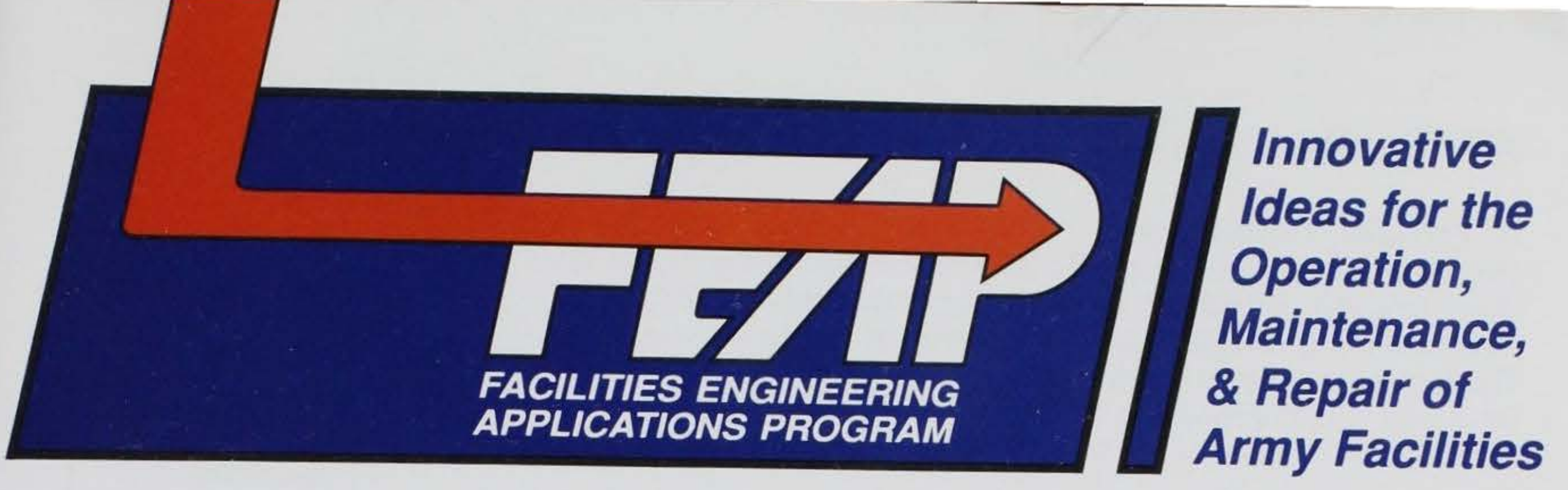

\section{Geotextiles}

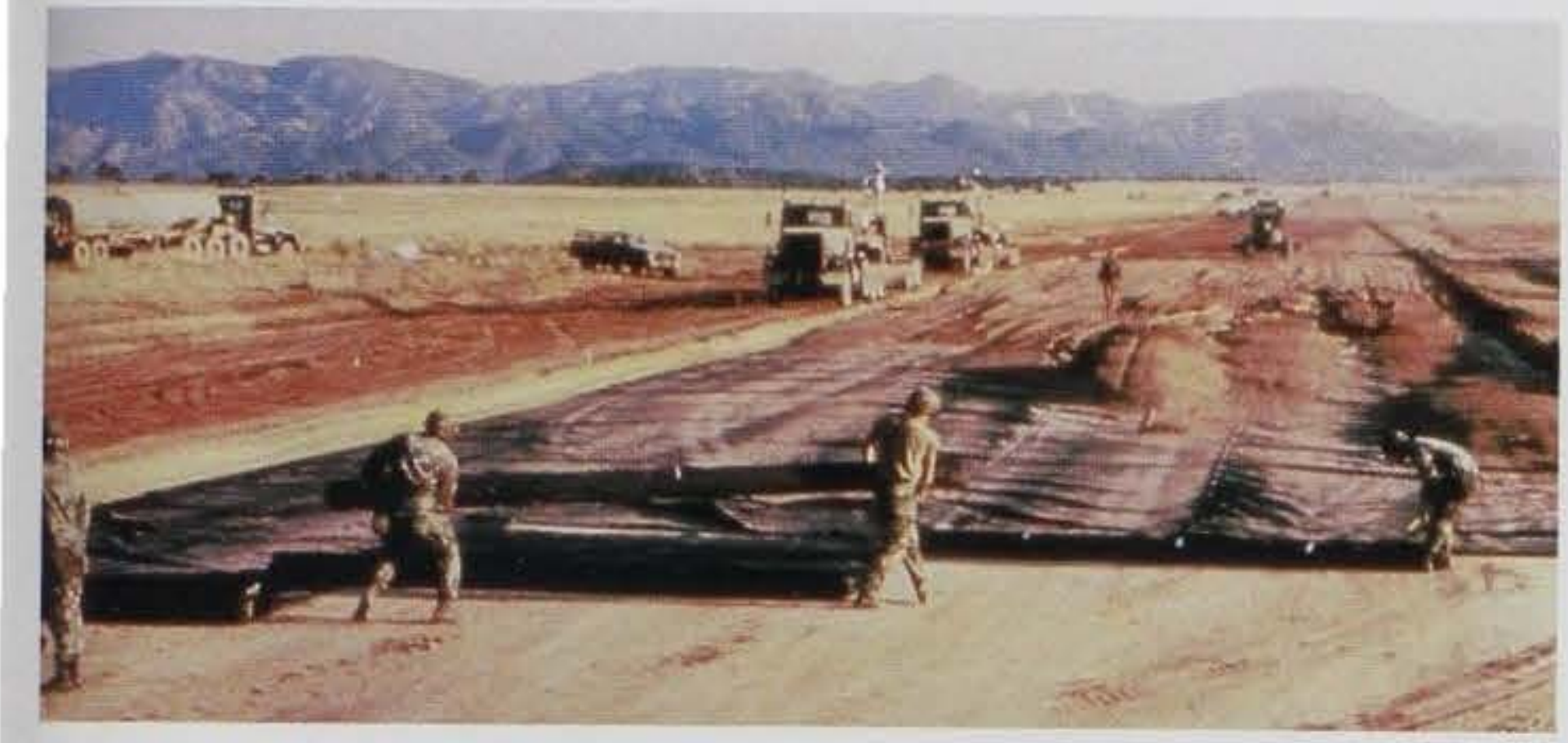

Engineer troops place the geotextile on compacted subgrade during construction of an airstrip at Ft. Carson, CO.

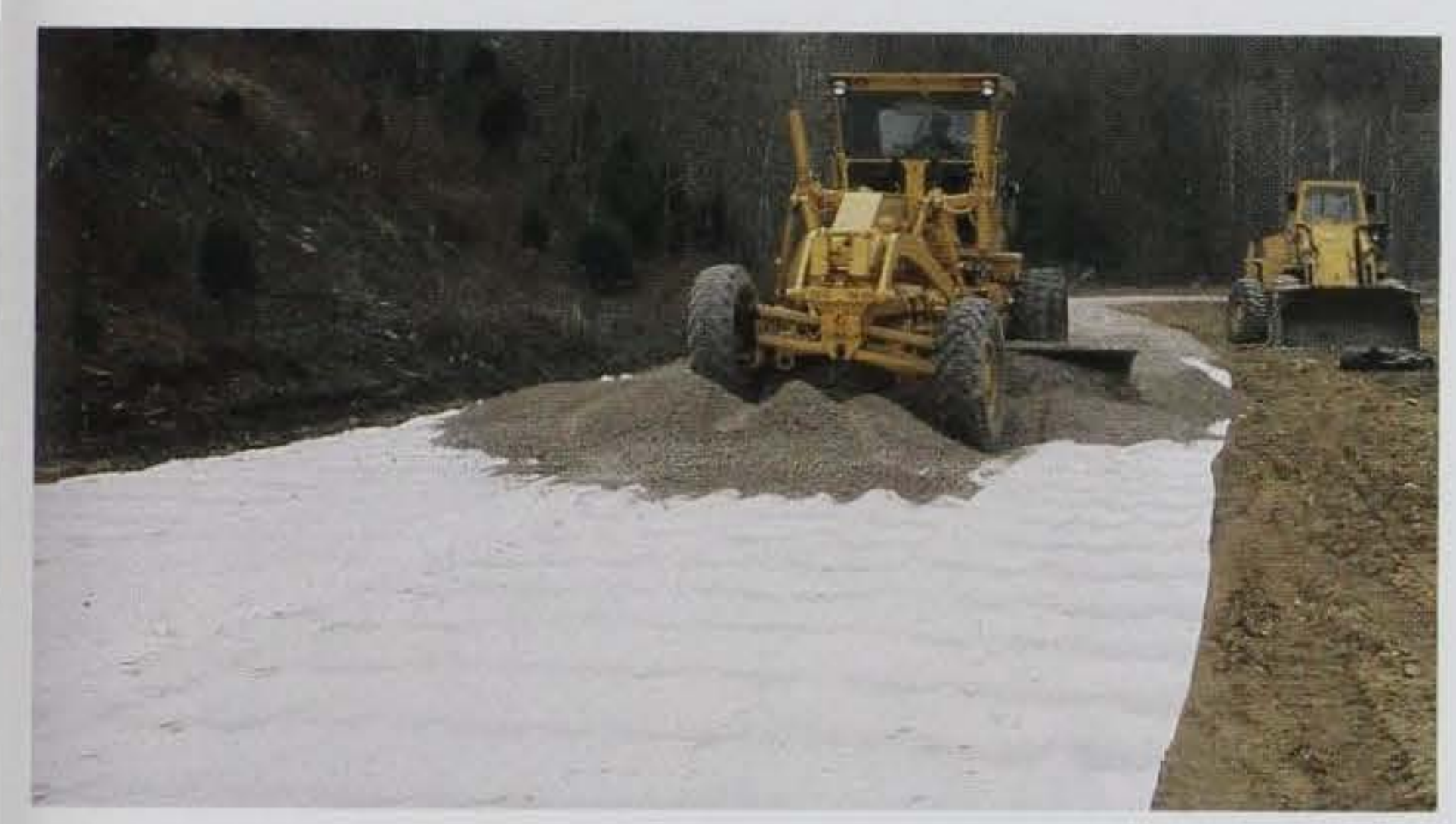

The aggregate is spread using a motor grader.

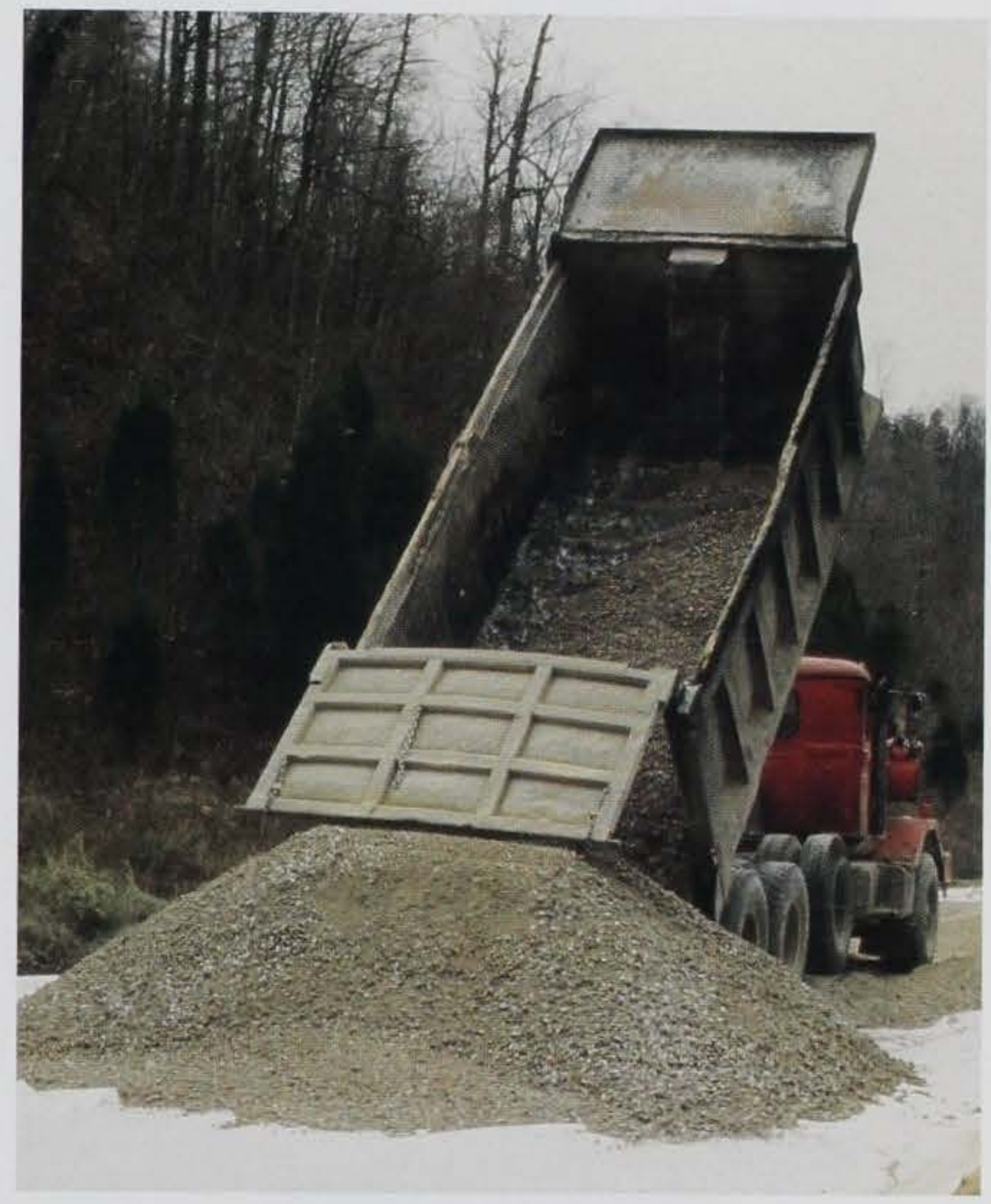

After the geotextile was placed on the range road at Ft. Knox, aggregate was dumped directly on it.

\section{Prevent Subsurface Erosion and Pavement Failure}

PROBLEM: Failure of civil engineering structures due to saturation or erosion of the soil or subgrade

TECHNOLOGY: Geotextiles made of synthetic fibers specially formulated for civil engineering applications can perform up to six basic functions:
- Filtration
- Screening
- Erosion control
- Reinforcement
- Drainage
- Separation

DEMO SITES: Fort Carson, CO FY88 Fort Knox, KY FY89

BENEFITS: - Easy, effective installation

- Less maintenance

- Necessary repairs less expensive

- Economically feasible way to create all-weather roadways 


\section{All-Weather Surfaces Made Possible With Geotextiles}

\section{A Versatile Technology}

Geotextiles are permeable textile (fabric) materials made out of synthetic

fibers specially formulated for civil engineering applications. Most

manufactured geotextiles fall into a woven or nonwoven classification.

The type of geotextile selected for an application will depend on the purpose for which it is intended. In any one application, the geotextile may be performing one or more of six basic functions.

The primary function currently demonstrated under FEAP is separation. Separation keeps the subgrade from intruding into the soil surface, or the soil from intruding into the gravel or pavement overlay.

FUNCTIONS:

Separation

Drainage

Reinforcement

Screening

Filtration

Erosion Control

\section{Geotextiles Demonstrated Successfully}

\section{Ft. Carson}

The first FEAP geotextile demonstration took place at Fort Carson, CO, in September 1988. The Red Devil airstrip at this site had required heavy maintenance in the past because erosion of the soft clay subgrade created severe problems with rutting. During wet periods, the runway could not be used. To solve this problem, U.S. Army troops of the 52nd Engineer Battalion reconstructed the 60 -ft-wide by 5,000 -ft-long airstrip using a geotextile. In addition to the separation function, the geotextile also serves as a filter, replacing the sand subbase/filter layer generally required over subgrades in climates susceptible to frost.

\section{Ft. Knox}

Fort Knox, KY, was the site of the second geotextile demonstration in December, 1989. Here a range road required upgrading to allow trafficking in wet weather. Moisture was softening the existing lean clay, making travel almost impossible. A quarter mile of the road was widened to 28 feet. In addition, drainage structures, including cross drains and drainage ditches, were improved. A minimum of 6 inches of graded stone was placed over a layer of geotextile which serves to separate the gravel from the soft clay soil. The Fort Knox DEH performed the work with standard construction equipment.

\section{Costs/Benefits of Using Geotextiles}

Geotextile costs generally range from approximately $\$ 0.40$ to $\$ 1.50$ per square yard, depending on the geotextile survivability requirements and the type and amount of geotextile needed. At Ft. Carson the average cost per square yard was $\$ 0.64$. At Ft. Knox it was $\$ 0.59$.

Benefits include:

* Easy, effective installation

* Gravel overlay thickness may be cut by $30-50$ percent

* Less maintenance required

* Necessary maintenance will cost less

* Cost savings over alternative solutions

* Economically feasible way to create all-weather roadways

\section{Procurement Information - Geotextiles Readily Available}

This technology can be implemented by any local contractor due to the use of standard construction procedures and the current widespread use and availability of geotextiles. A Corps of Engineers Guide Specification and Technical Manual are currently being drafted.

For more information please contact:

James E. Shoenberger or Richard H. Grau, U.S. Army Engineer Waterways Experiment Station (WES), 3909 Halls Ferry Road, Vicksburg, MS 39180-6199, COMM 601-634-3553 or toll-free 800-522-6937 x3553. Ken Gregg, U.S. Army Engineering and Housing Support Center (USAEHSC), 703-355-3582. 